\title{
TO BREASTFEED OR NOT TO BREASTFEED? THAT IS THE QUESTION.
}

\section{JACQUI MÝBURGH}

\section{OPSOMMING}

Die skrywer het die hipotese dat meer kleurling as blanke rroue op ses weke post-partum nog borsvoed in 'n navorsingsprojek getoets.

Daar is bevind dat kleurlinge wel meer suksesvol is met borsvoeding as blankes. Maatskaplike faktore soos ouderdom, huwelikstaat en parièteit het nie 'n betekenisvolle invloed op bors voeding gehad nie. Die skrywers maak 'n aantal voorstelle wat verpleegkundiges in gedagte moet hou om borsvoeding effektief te bevorder.

\section{INTRODUCTION}

The following research was carried out during the eight weeks of August and September 1982. It involved coloured and white patients. Our interest, was to determine how successful coloureds and whites in Johannesburg were at breastfeeding at the time of their six week postnatal check-up.

\section{PURPOSE OF STUDY}

Our reason for doing the study was that during our midwifery training we noticed that many mothers had given up breastfeeding within six weeks despite educational programmes held at the Hospital. As our dealings were primarily with whites we wondered whether this was also the case with other sectors of the population and whether their educational programmes in promoting breastfeeding were better or worse.

\footnotetext{
This article is based on research conducted as part of the authors' final year requirements for the degree BSC (Nursing) at the University of the Witwatersrand, 1982. The research project won the 1983 Juta Nursing Research Prize in the category for students on a course for a basic degree or diploma in Nursing.
}

\section{METHOD}

We were limited to the coloured sector of the population because of unforseen circumstances and refusal to conduct a survey from chosen black hospitals. The hospitals we used were registered as university training centres for degree and non-degree nurses and other members of the health team.

Initially a pilot study was conducted on 20 coloured mothers. The necessary modifications were made to the instrument which, in this case, was a questionnaire and interview.

The following sample sizes were obtained:

62 Coloured mothers answered the questionnaire of which twelve were considered spoilt, as they had not been checked by us immediately after being answered and many items had been overlooked. Therefore we had a usable sample of 50 .

Exactly 50 white mothers were interviewed and there was a $100 \%$ return.

\section{DEFINITIONS}

A specific explanation of terminology used is necessary.

- Government definition of a coloured and white according to the Population Registration Act No. 30 of 1950.

A coloured person is a person who is not a white of black (obtained telephonically from The Department of Race Relations in Pretoria).

A white person is one who:(a) in appearance obviously is a white person and who is not generally accepted as a coloured person; $O R(b)$ is generally accepted as a white person and is not in appearance obviously a white person.
- By the terms successful or better breastfeeders it is implied that there are more people in one group breastfeeding than in the other. There is no reference to the actual technique of breastfeeding.

\section{HYPOTHESIS}

Coloureds are more successful breastfeeders than whites at six weeks post partum.

\section{SUB HYPOTHESES}

- Coloureds are more successful probably due to socio-economic circumstances such as poorer living conditions which include smaller and overcrowded dwellings.

- Guidance and health education, ante- and post-natally plays an important role in increasing the rate of breastfeeding.

- Mothers are not really aware of the advantages and disadvantages of breastfeeding despite educational programmes.

- Encouraging husbands play an important role in increasing the success rate.

- Married mothers are better breastfeeders than single mothers.

- The level of education does not necessarily influence the success rate of breastfeeding, but it influences the awareness of the advantages and disadvantages.

- Non-working mothers are better breatfeeders than working mothers.

- Young adults (above the age of 21) are better breastfeeders than teenagers (13-20).

- Multigravidas are better and more successful breastfeeders than primi-paras. 


\section{CULTURAL ASPECTS OF BREASTFEEDING}

In an article entitled Human Milk in the Modern World reasons are listed for a decline in breastfeeding. The authors say it is due to a variable blend of interacting sociological factors. These are summarised below as a modification of the classification of Dwyer \& Meyer (1975), Valquist (1975) and others.

- - Rapid urbanisation, industrialisation and change in status of females leads to increased numbers of women working.

- Altered family structure (small, nuclear, two generation family).

- Alleged convenience of bottle feeding.

- Western urban attitude to

female breasts (privacy for breast-feeding - clothes increase difficulties).

- Insufficient action by the Government to encourage breastfeeding.

- Failure to provide crèches for working mothers.

- Inadequate attention to appropriate legislation to support lactation.

- Nutrition welfare programme that tends to diminish breastfeeding.

- Lack of attention to human milk as a national food resource.

- Minimal or absent effective health education especially via mass media.

- Negative effect of health and nutritional professionals.

- Increasing hospital deliveries with indifferent or disruptive regimes, and confusing advice in maternity units.

- Lactation-inhibiting contraceptive pills.

- Lack of emphasis on diet of pregnant and lactating women.

- Marketing, advertising and promotion of formulae.

- Manipulative advertising.

- Influencing of health personnel, such as giving of free samples.

\section{RESULTS AND INTERPRETATION OF STUDY}

After correlating the data it was found that the sample of 50

\section{Table 1. Mean age and range of ages of sample.}

\begin{tabular}{|lrr|}
\hline & Whites & Coloureds \\
\hline Mean age (years) & 24,8 & 24,78 \\
Range of ages & $16-42$ & $15-39$ \\
\hline
\end{tabular}

Table 2. Percentage distribution of level of education reached by mothers.

\begin{tabular}{|lrr|}
\hline Level of education & Whites & Coloureds \\
\hline Standard 10 & $40 \%$ & $30 \%$ \\
9 & $32 \%$ & $14 \%$ \\
8 & $8 \%$ & $12 \%$ \\
7 & $16 \%$ & $16 \%$ \\
6 & $2 \%$ & $12 \%$ \\
5 & $2 \%$ & $16 \%$ \\
\hline
\end{tabular}

Table 3. Percentage

\section{distribution of the working}

status of the mothers.

\begin{tabular}{|c|c|c|c|c|c|}
\hline \multicolumn{2}{|c|}{ Working } & \multicolumn{2}{|c|}{ Not working } & \multicolumn{2}{|c|}{ Want to work } \\
\hline $\begin{array}{l}W \\
14 \%\end{array}$ & $\begin{array}{l}\text { C } \\
28 \%\end{array}$ & $\begin{array}{l}W \\
86 \%\end{array}$ & $\begin{array}{l}\text { C } \\
72 \%\end{array}$ & $\begin{array}{l}w \\
34,9 \%\end{array}$ & $\begin{array}{l}\mathrm{C} \\
80,6 \%\end{array}$ \\
\hline \multicolumn{6}{|c|}{$\mathbf{W}=$ whites } \\
\hline \multicolumn{6}{|c|}{$\mathrm{C}=$ coloureds } \\
\hline
\end{tabular}

Tabel 4. Percentage rates of white mothers breast-feeding, compared to coloured mothers who were breastfeeding.

\begin{tabular}{|ll|}
\hline White & Coloured \\
\hline $48 \%$ & $78 \%$ \\
\hline
\end{tabular}

Tabel 5. The percentage of coloured and white mothers who received guidance.

\begin{tabular}{|lll|}
\hline & $\begin{array}{l}\text { Guidance } \\
\text { received }\end{array}$ & $\begin{array}{l}\text { Guidance not } \\
\text { received }\end{array}$ \\
\hline Whites & $66 \%$ & $34 \%$ \\
Coloureds & $54 \%$ & $46 \%$ \\
\hline
\end{tabular}

coloured and 50 white mothers attending their post-natal check-ups had the social characteristics as indicated in tables 1-3.

\section{DISCUSSION OF FINDINGS}

\section{Breastfeeding rates}

The coloureds had a higher incidence of breastfeeding than the whites (see table 4 ) and this was significant at $p=0,00$. Therefore this can be generalised to the total coloured and white population, that is coloureds have a higher incidence of breastfeeding than whites and are more successful.

\section{Influence of social factors.}

Taking the total sample, age does affect breastfeeding rates and the highest rate of breastfeeders in various age groups differed between coloureds and whites. Coloureds had the bulk of breastfeeding mothers in the age group 16-25, due to there being more single mothers among the coloureds. In whites the highest percentage of breastfeeding mothers were over 21 years of age.

Marital status had no effect on the rate of breastfeeding at the 0,05 significance level. Parity in general was also independant of the success rate of breastfeeding between coloureds and whites.

Coloured mothers had a higher incidence of breastfeeding despite working status. It was felt that this may have been due to their lower socio-economic status as compared to whites. More coloured mothers need to work to possibly improve the family income and more may be breastfeeding because it is cheaper.

\section{Effect of guidance}

In the sample studied, it seems that whites received more guidance on the whole than coloureds (see table 5). However coloureds in the sample were more successful despite guidance given. This may mean that the guidance given to the whites may not be effective or extensive enough and is not necessarily the only factor influencing successful breastfeeding. 
Mothers were not aware of the advantages and disadvantages of breastfeeding. Therefore health education programmes are either ineffective or not extensive enough. The latter was found to be more true.

It was also found that husband encouragement does not play an important role in breastfeeding.

The level of education does not necessarily affect the success rate of breastfeeding but increases awareness of advantages.

\section{ROLE OF THE NURSE AS PROMOTER OF BREAST- FEEDING}

Listed below are a number of facts that the educator (nurse, doctor, paramedic) should bear in mind if they are to perform an effective role as a teacher.

- Spend time with the patient and allow for questions and answers.

- Never be so busy that you cannot be interupted with questions.

- Spend time reading over literature with patient and answering queries.

- Supply the mother with assurance and encouragement.

- Intensive counselling to mothers ante- and post-natally.

- Emphasise advantages of breastfeeding in a language that can be understood.

- Obstetricians and paediatricians should work together and promote breastfeeding.

- Medical personnel should be up to date with current concepts in breastfeeding - achieved by reading journals, periodicals and attending seminars.

- Base education on the cultural and economic environment of the community.

- As midwives we should have a positive attitude toward breastfeeding and therefore create a socially acceptable situation. We must not project our own personal feelings and attitudes.

- We must aim to gain the confidence of the mothers and be good listeners.

- Breastfeeding should be advertised by means of radio, television, newspapers and posters.
- When unavoidable reasons on the part of the mother or baby are apparent for not breastfeeding, they must be recognised. The midwife should then advise the mother on the best possible alternative for feeding using a bottle and a substitute milk formula.

\section{LIMITATIONS}

As with any study of this kind, certain limitations are imposed - by circumstance, by those directing and by those researching.

The most severe limitation of this study was the time factor, due to the authors still being student nurses. They still had a full quota of ward hours to complete and as degree students had lectures to attend and studying to do. The topic was extremely wide for two students to cope with.

Unanticipated factors were the length of time it took hospitals to reply and refusal to conduct surveys. As a result the topic had to be modified.

The inter-racial nature of the population was a limiting factor as some of the wording used in the questionnaire was not understood by the coloured mothers. This was corrected on administration of the instrument). There is a limited amount of literature available on breastfeeding success rates in the different population groups and thus the formulation of the questionnaire was based partly on the literary review and partly on trial and error.

\section{RECOMMENDATIONS FOR FURTHER STUDY}

- Does the economic status of coloureds and whites affect the rate of breastfeeding in married mothers?

- Motivating factors in influencing primiparas and multiparas to breastfeed (parity was found to not necessarily influence rates of breast-feeding).

- Investigate reasons for mothers wanting to return to work, or reasons for working and correlate it with their economic status, such as income.
- Find the working and breastfeeding status in larger samples of white and coloured women and do significance levels.

- Have mothers who want to work stopped breastfeeding so they can return to work; or is the desire to want to work an excuse for not breastfeeding?

- Determine the significance of education levels and success rate of breastfeeding.

\section{CONCLUSION}

It was found that the success rate of the two population groups differed significantly in the Johannesburg area at six weeks post-partum. There is still a high rate of unnecessary bottle feeding and the increase of bottle feeding is a phenomenon of urbanisation. As a result of this, it is the moral and legal duty (according to South African Nursing Council Rules and Regulations) for registered midwives to promote breastfeeding. This must be accompanied by constant re-assessment and revaluation of our health education programme for improvements to be made.

It was felt that this study was important in nursing research to make nurses aware of the ratio of bottlefeeding and breastfeeding in all the population groups for the reasons given below.

- It may aid us to learn from the achievements of nurses in other population groups in the promotion of breastfeeding.

- By comparing race groups, we may learn why one group is more successful than another.

- By assessing rates of breastfeeding and comparing them to educational programmes, it may be used as a form of evaluating the health educational programmes.

- It is interesting and enlightening.

- By studying more than one race group, nurses learn about the cultural and ethnic aspects of these race groups so that she may care for all humanity with understanding of differences between the various race groups and cultures.

Continued on p.48 